\title{
Moving Transfer to Transformative Learning: A Curriculum Model for Adult Educators in Open Distance Learning (ODL)
}

\author{
Dr Esther Njiro \\ Senior Lecturer, ABET and Youth Development, School of Educational Studies, College of Education, \\ University of South Africa, No. 1 Preller Street, Muckleneuk Campus, \\ Pretoria, P O Box 392, UNISA, 0003, South Africa \\ Email: njiroei@unisa.ac.za
}

\section{Doi:10.5901/jesr.2014.v4n3p479}

\begin{abstract}
This article reviews the literature on theories of adult learning particularly transfer and transformative learning and how they inform a model curriculum for adult educators in open distance learning $(O D L)$. On-line instructions have to change from the habitual teacher-based to more inclusive and integrating transformative learner-centred learning designs. Continuous professional development of educators of adults needs to be transformative if they are to measure up to growing demand for adult education. Currently the adult educators are not receiving relevant training for deep learning and change. With the rapid pace of technology in the fast-paced knowledge economy self-directed transformative learning must inform curriculum. Adult educators need proactive institutional contexts that stimulate them to deep learning.
\end{abstract}

Keywords: Transfer, Knowledge, Transformative, Learning, Curriculum, Model,

\section{Introduction}

"Every person child, youth, and adult shall benefit from educational opportunities designed to meet their basic learning needs" (World Conference on Education 1990; article 1).

The central question of how adults learn has occupied the attention of scholars and practitioners since the founding of adult education as a professional field of practice in the 1920s (Merriam (2001:1). Most educators of adults never had opportunity to learn adult teaching. They enter through a circuitous route which does not include teacher training. Many are enrolling in open distance learning (ODL) institutions to study adult education (Cranton and King 2003:31). Traditional education conditioned learners to be dependent on teachers to make decisions for them about what should be learned how it should be learned when and if it has been learned (Bennetsa, Ellistonto and Maconachiec (2012:2).Professional development opportunities even when they are available do not ground adult educators in adult learning. Often the professional development courses are instructor-designed and led for students to attend training and learn from a "sage on the stage" (Tweedell 2000).

\section{The Purpose of this Paper}

This paper set out to find out what informs the current ABET curriculum at University of South Africa (UNISA) an ODL institution. According to Aitchison (personal conversation November1, 2013) there seems to be a general consensus that the current $A B E T$ qualifications are very unsatisfactory and have not responded to the real needs and situations of adults. Strictly speaking there is no ABET curriculum as officially ABET simply has a set of outcomes-based standards. It is up to the provider (whether state or private) to devise and register with South African Qualifications Authority (SAQA) the programme/qualification and set up a curriculum to achieve those standards. A number of General Education and Training Certificate (GETC) in ABET variants registered with the South African Qualifications Authority by listing the components required to gain an ABET qualification Van Rooy (2001).

The study for this paper set out to show the need to move from training or transfer to transformative learning by adult educators. A review of transfer and transformative selected theories was carried out before analysis of how these theories could be used to inform a model curriculum to instruct adult educators.

Adult basic education and Training (ABET) in South Africa is defined as 
the general conceptual foundation towards lifelong learning and development, comprising of knowledge, skills and attitudes required for social, economic and political participation and transformation applicable to a range of contexts. $A B E T$ is flexible, developmental and targeted at the specific needs of particular audiences and, ideally, provides access to nationally recognised certificates (Department of Education 2001).

In Africa and South Africa adult education tends to be conceptualised and defined as literacy, basic education, and livelihood-related skills training (UNESCO 2009:5). Furthermore the authors said that adult learning is generally marginalised in most African countries where it is usually aligned to other social developmental activities such as health, economy, labour and rural development (Walters 2006). Social goals such as gender equality social cohesion, active citizenship, cultural and linguistic diversity are associated with adult learning. Lack of recognised national policies has negative impacts on development of relevant curriculum for educating adult educators.

$A B E T$ introduces a culture of learning and provides the foundations for acquiring the knowledge and skills required for social and economic development, justice and equality. ABET provides access to further and higher education and training and employment. The term 'adult basic education and training' or ABET "subsumes both literacy and postliteracy as it seeks to connect literacy with basic (general) adult education on the one hand and with training for income generation on the other hand". Thus ABET precedes further education and training (FET). Taken together ABET and FET, the two components of adult education and training (AET), progressively initiates adult learners onto a path of lifelong learning and development.

Most adult's experience of learning is in passivity in predominantly instructor designed and led curriculum (Tweedell 2000) Today adult educators like other teachers have to quickly adapt the rapidly changing technology particularly in open distance learning (ODL) institutions. Professional instructional designers have to understand transformative learning theories that explain the way adults learn: the nature of adult learning and distance learning (Moore and Kearsley 1996:153).

Adult learners are different from traditional college students. Many adult learners have responsibilities (e.g., families and jobs) and situations (e.g., transportation, childcare, domestic violence and the need to earn an income) that can interfere with the learning process. Most adults enter educational programs voluntarily and manage their classes around work and family responsibilities. Additionally, most adult learners are highly motivated and task-oriented (Merriam and Caffarella, 1999). Adult learners face many challenges unlike ordinary university students: multiple careers. They have fewer supportive social structures to rely on as they cope with living longer and caring for parents who now live longer. Adults are insecure in decision-making as life is complex making lifelong learning a necessity rather than an option.

Learning for everyone is about change and adult learning theories are to assist instructors of educators of adults design meaningful instructions. There is no one adult learning theory that applies to all adult learning contexts just as there is no one theory that explains human learning. Existing theories provide frameworks or models to understand adults as learners (Merriam and Caffarella 1999:271)

Deepen understanding of transfer of learning and transformative learning theories for instructional designers of ABET curriculum at an ODL institution is imperative. Adult learning has a varied scope as some view it as gaining freedom from the oppression of illiteracy. Others consider it to be a means of gaining knowledge and skills while some see it as a form of critical reflection that might lead to transformation Cranton 1994).

\section{Transfer of Learning}

Transfer of learning is a process whereby learning occurring in one context enhances or undermines a related performance in another area (Perkins and Salomon 1992, Harris, Lowery-More and Farrow 2009:319). Applying knowledge learned in one situation in another one is the evidence that transfer of learning has occurred. Research has however revealed that just because instructions are provided learning may not happen. Thorndike's early $20^{\text {th }}$ century studies have been confirmed by more recent studies of Perkins and Salomon (1996) Harris et.al (2009) that people do not often understand how to apply what they learn to various situations as they are not able to make connections expected of them.

This view was confirmed by many instructional designers characterised by assumptions that transfer will take care of itself and it usually does not. Transfer of learning is essential particularly for designers of ODL materials. Instructional designers often assume that transfer takes care of itself once the instructions are disseminated. There is a critical difference between learning during instruction and application of that learning in the real world. An example is when emarking was introduced at UNISA and instructions were given in a room that did not have computers for lecturers to 
practice how to do on-screen marking. The difficult for many was shown by repeated attendance of the same training as they were not able to mark using the J-Router marking tools. Clearly real life application of what is learnt is always much more complex than the instruction given. What is needed is a high road transfer where performance requires a fair degree of judgement and skills are performed in varied practices, self-monitoring and generalising about application to the real world (Harris et.al. 2009).

\section{Andragogy Science and Art of Adult Learning}

Adult education may be understood as an organised effort to assist those who are old enough to be held responsible for their acts acquire or enhance their skills, knowledge and dispositions Mezirow (2000). Andragogy was the rallying point for those trying to differentiate working with the actual interests of learners instead of focusing on what instructors believed were learners" interests. In Knowles view (Knowles 1988) the best educational experiences were cooperative, guided interactions between the teacher and learner(s) through many available learning resources. During these experiences, the teacher helps guide the learner(s) to develop his or her own potential. Based on his own observations, Knowles developed a set of five assumptions about how adults learn (Merriam \& Caffarella, 1999). Table one below describes these:

Table I: Knowles Assumptions of Adult learning

\begin{tabular}{|c|c|}
\hline $\begin{array}{l}\text { Adults have an independent self- } \\
\text { concept a self-directed learner } \\
\text { (Knowles 1988). }\end{array}$ & $\begin{array}{l}\text { During the period of maturation adult become autonomous, independent and self-reliant. There } \\
\text { are however some different rates as those with previous schooling have dependency } \\
\text { constructed. A curriculum model should encourage adult educators to move learners from their } \\
\text { old habits. They should encourage them to take responsibility for their learning and be self- } \\
\text { directed (Fidishun 2000). Instructors should facilitate knowledge of how to become self-reliant } \\
\text { learner. }\end{array}$ \\
\hline $\begin{array}{l}\text { Adults have a reservoir of life } \\
\text { experiences that is a rich resource for } \\
\text { learning (Merriam and Caffarella } \\
1999: 272)\end{array}$ & $\begin{array}{l}\text { The process of growing up accumulates learned experiences. In learning new things adult } \\
\text { learners can build on previous knowledge and experience. Curriculum should be relating new } \\
\text { information to student's past events and to concepts being learned. Kolb1984:38 agreed that } \\
\text { recognising and acknowledging adult-based learning experiences is a powerful method for } \\
\text { teaching adult learners. Accumulated life experiences and knowledge need to be connected to } \\
\text { new knowledge. }\end{array}$ \\
\hline $\begin{array}{l}\text { Adult's readiness to learn is closely } \\
\text { related to their changing social roles. } \\
\text { They enter educational settings ready } \\
\text { to learn (Merriam 2001:3). }\end{array}$ & $\begin{array}{l}\text { Adults are goal-oriented and the study objectives should be clearly outlined in a given course. } \\
\text { They usually know what they want to learn. Educators should provide real life tasks with tools } \\
\text { and procedures that assist the leaner discover their need to know. }\end{array}$ \\
\hline $\begin{array}{l}\text { Adults are problem-centred and } \\
\text { interested in immediate application of } \\
\text { knowledge. }\end{array}$ & $\begin{array}{l}\text { Adult learners need to know why they should learn something and how it will benefit } \\
\text { Knowles 198). They are relevance-oriented and want to see a reason for learning th } \\
\text { applicable to their work. A curriculum should be organised around competency developme } \\
\text { adults are performance-centred. Instructors should direct students to reflect on what they in } \\
\text { to learn and how it will help them meet their goals. }\end{array}$ \\
\hline $\begin{array}{l}\text { Adults are motivated to learn by } \\
\text { internal rather than by external } \\
\text { factors }\end{array}$ & Some factors that motivate adults include job satisfaction, promises of promotion \\
\hline
\end{tabular}

Adult education literature has recently addressed professional development and teacher education as adult learning. Premiere among these are the work of Brookfield (1995) and Cranton (1996) who say it is not clear how adults learn as everyone is different and shaped by his or her history and contexts. Learning is about change and adult learning theory helps in creating a curriculum that leads to more meaningful learning experiences for adults (Cercone 2008:231).Constructivists philosophy emphasizes learner-centred interpretations and explorations.

\section{Transformational Learning}

Transformative learning refers to change related to what learning produces. All learning produces change of some kind but transformational learning produces far-reaching changes in the learners than does learning in general, and that these changes have a significant impact on the learner's subsequent experiences (Clark 1993). Transformative learning theory is about students undergoing a major change in their understanding of a phenomenon as a result of particular learning 
experience/activities.

Transformative learning is an idealised model for adult learning that distinguishes learners as receptacles of knowledge versus learners who are actively engaged through critical reflection and discourse (Dirkx 1998:3). Transforming is a problematic frame of reference to make it more dependable by questioning assumptions, expectations, and context to achieve deeper meaning and new perspectives to guide their actions. Clark 1993 and Dirkx 1998 presented various "strands" of transformative learning as reflected in the work of several adult educators. We shall briefly summarise the works of Paulo Freire and Jack Mezirow as a way of understanding the role of transformative learning on adults.

\section{Transformation as Conscientization or Consciousness-Raising}

Freire's (2000) notion of emancipatory education articulated transformative consciousness-raising among the poor illiterates in Brazil. He helped them realise that the "banking" education method of emphasising passive listening and acceptance of facts kept by instructors disenfranchised learners. Critical consciousness the process in which learners develop ability to analyse pose questions and take action on social, political and economic contexts that shape their lives was important. Adult learning develops awareness of structures that contributed to their oppression and inequity. Believing that education was for the purpose of liberation, Freire's students discussed and reflected on relevant life issues such as the inadequate pay they received as rural workers. Through this process, workers recognised the larger societal structures that oppressed them and how they could overcome these barriers. Empowered in their new perspective, they could act to transform their world.

\section{Perspective Transformative Learning}

Transformative learning theory was first articulated by Jack Mezirow of Columbia University in the 1970's, with the resulting conclusion that perspective transformation was key. He went on to describe a 10 phase transformation processes which emerged during transformation as follows:

- A disorienting dilemma

- A self -examination with feelings of guilt or shame

- A critical assessment of epistemic, sociocultural, or psychic assumptions

- Recognition that one's discontent and the process of transformation are shared and that others have negotiated a similar change

- Exploration of options for new roles, relationships, and actions

- Planning a course of action

- Acquisition of knowledge and skills for implementing one's plan

- Provision trying of new roles

- Building of competence and self-confidence in new roles and relationships

- A reintegration into one's life on the basis of conditions dictated by one's perspective

While Freire's focus is social-justice oriented, Mezirow concentrates on the importance of rational thought and reflection in the transformative learning process. Several fundamental components make up the recursive process that Mezirow delineates for perspective transformation. The process begins with a "disorienting dilemma" (Mezirow, 2000: 168), People engage in critical reflection and re-evaluate the assumptions they have made about themselves and their world. This happens when people "realise something is not consistent with what they hold to be true" (Taylor, 1998:9).

Reflections on their meaning perspectives or their overarching "structure of assumptions" or their meaning schemes, which include their beliefs and values or "habitual, implicit rules for interpreting experience," can result in a perspective transformation or change in world view (Mezirow, 2000:2). Third, people engage in "reflective discourse" (Mezirow, 2000: 11). In short, they talk with others about their new perspective to obtain consensual validation. Finally, action on the new perspective is imperative. In other words, not only seeing, but living the new perspective is necessary.

Mezirow (2000) acknowledges the importance of emotions for meaning-making process. Learning occurs "in the real complex world where institutional, interpersonal, and historical settings and cultural orientations embodied in our frames of reference" interfere with learning (p. 24). There are "asymmetrical power relationships" that influence the learning processes (p. 28). Social interactions are acknowledged as important in the learning relationships. 


\section{Towards Adult Educator's Transformative Learning Curriculum}

Adults' perspective transformations are frequently prompted by "disorienting dilemmas", and proceed through multiple stages of progression (Mezirow 2000). In a similar fashion, revised state and national standards, school administrators, accrediting organisations, professional associations, parents, peers, students, and the community are requiring that teachers learn technology and effectively integrate it into their curriculum. These forces create an intense demand for educators to cope with constantly changing technology and may result in teachers experiencing a "disorienting dilemma" or "trigger event" that urges them to pursue technology in education. Conditions like these cause adults to question their knowledge-base and to change their actions are the seedbeds of additional profound change in perspective transformation experiences.

\section{A Transformative Curriculum Model}

Table one below demonstrates how a transformative curriculum model for ABET can incorporate technology in an ODL context.

Table 1: A transformative curriculum model

\begin{tabular}{|l|l|l|}
\hline Maslow's 10 steps for TL & Teaching strategies & $\begin{array}{l}\text { ODL Technologies supporting the } \\
\text { activities }\end{array}$ \\
\hline Disorienting dilemma & $\begin{array}{l}\text { Establishing a climate conducive to } \\
\text { learning; narrative stories recalling crisis }\end{array}$ & Facebook, socio video podcast and blog \\
\hline Self-examination + feelings & $\begin{array}{l}\text { Journal writing; empathetic conversation } \\
\text { Individual and group, metacognition \& } \\
\text { reflection }\end{array}$ & Blog, communication tools, chat \\
\hline $\begin{array}{l}\text { Critical assessment of epistemic social- } \\
\text { cultural or psychic assumptions }\end{array}$ & $\begin{array}{l}\text { Small group discussions; interview people } \\
\text { with similar experiences }\end{array}$ & Web-conference discussion forums \\
\hline $\begin{array}{l}\text { Recognition that one's discontent and the } \\
\text { process of transformation are shared and that } \\
\text { others have negotiated a similar change }\end{array}$ & $\begin{array}{l}\text { Conducting these learning experiences } \\
\text { with suitable techniques and materials }\end{array}$ & $\begin{array}{l}\text { Threaded discussion Forums and web } \\
\text { conference }\end{array}$ \\
\hline $\begin{array}{l}\text { Exploration of options for new roles, } \\
\text { relationships and actions }\end{array}$ & Diagnosing the needs for learning & $\begin{array}{l}\text { Concept map, wiki, Facebook, social } \\
\text { networks }\end{array}$ \\
\hline Planning a course of action & Creating a mechanism for mutual planning & $\begin{array}{l}\text { Forum, internet search Google, schedule } \\
\text { calendar }\end{array}$ \\
\hline $\begin{array}{l}\text { Acquisition of knowledge and skills for } \\
\text { implementing ones plan }\end{array}$ & Problem based Collaborative writing & Online learning LMS, Sakai \\
\hline $\begin{array}{l}\text { Provision trying of new ones } \\
\text { Fuilding of competence and self-confidence }\end{array}$ & Formulating program objectives & $\begin{array}{l}\text { Journal writing of discussion after trips, } \\
\text { conference with people in the field, Virtual } \\
\text { world stimulation gaming }\end{array}$ \\
\hline $\begin{array}{l}\text { A reintegration into one's life on the basis of } \\
\text { conditions dictated by ones perspectives }\end{array}$ & $\begin{array}{l}\text { Evaluating the learning outcomes and re- } \\
\text { diagnosing learning needs }\end{array}$ & $\begin{array}{l}\text { Digital story-telling } \\
\text { design and deliver }\end{array}$ \\
\hline
\end{tabular}

\section{Conclusions}

Clearly there are many divergent interpretations and assumptions of transfer and transformative theories of adult learning that they have evolved and expanded over time. Our discussion focused on the diverse views about transformation in ABET at an ODL institution and how it can inform the curriculum of educating adult educators.

We have seen that unlike transfer during training, transformative learning identifies forces that shape, constrain or limit learning and it frees learners from their coercive influence through reflection, dialogue and critique. Online learning environment is a viable context for applying transformative learning. It allows asynchronous time and mental space for reflection. Collaborative communication through social media tools inspires learning by individuals and communities. Adults are active, engaged participants in the learning process, co-creating or constructing what they are learning as they learn rather than taking in content or subject matter passively. As ODL instructors there is need to support transformative 
learning by considering content and skills as texts coming through the learners. Transformative learning brings a deeper way of understanding the meaning-making process of adults. Freire's perspective stresses the significance of social structures while Mezirow emphasis is self- actualization by individuals in their own contexts.

\section{Recommendations}

- The principles of adult learning theory can be used in the design of technology-based instruction to make it more effective.

- To facilitate the use of andragogy while teaching with technology we must use technology to its fullest. Arguments for the use of technology many times include statements about its flexibility and the ability of the learner to move through lessons anytime, anywhere, and at their own pace.

- Hybrid classes may pose an opportunity to develop interactive, collaborative learning communities not unlike entirely online courses.

- Hybrid online classroom discussions had the potential of prompting critical thinking, dynamic interactive dialogue, and substantial peer-to-peer interaction.

- There is participation of a depth and insight that might not be possible in traditional teaching.

- The principles of adult learning theory can be used in the design of technology-based instruction to make it more effective.

- To adapt to the needs of adult students, these definitions of technology-based learning must be utilized to make its design interactive, learner-centered and to facilitate self-direction in learners.

- Educators who are using adult education concepts in the development of their lessons must also become facilitators of learning.

\section{References}

Bennetts C, K. Elliston, M. Maconachie (2012) Continuing and Professional Development for Public health: Andragogical Approach. Graduate School of Education, College of Social Sciences and International Studies, University of Exeter, Exeter, UK.

Brookfield, S. (1995) Adult Learning an Overview in Tuinjman (ed.) International Encyclopaedia of I Education. Oxford Pergamon Press.

Cercone, K. (2008). Characteristics of adult learners with implications for online learning design, AACE Journal, 16(2), 137-159

Cranton, P. (1994) Understanding and Promoting Transformative Learning: A Guide for Educators of adults. San Francisco. JosseyBass.

Cranton, P. and K.P. King (2003) Transformative Learning as a Professional Development Goal. New Directions for Adults and Continuing Education 31-37.

Department of Education (2001) Policy Document on Adult Basic Education and Training. Government Press.

Dirkx, J.M (1998) Transformative Learning Theory in the Practice of Adult Education: An Overview in PAACE Journal of Lifelong Learning Vol. 7, 1998:1-14.

Habermas, J. (1971) Human interest and Knowledge. Boston: Beacon Press. (Originally published in 1921)

Harris, S. H. Lowery-Moore and V. Farrow (2009) Extending Transfer of Learning Theory to Transformative Learning Theory: A Model for Promoting Teacher Leadership; Department of Professional Pedagogy, Lamar University, Beaumont, TX Published online: 14 October.

King, K. P (2002) Educational technology professional development as transformative learning opportunities in Computers and education Volume 39 (3) :283-297.

Knowles, M. S. (1988) The Modern Practice of Adult Education: Andragogy Versus Pedagogy (Revised edition). Englewood Cliffs Prentice Hall Cambridge

Merriam S.B. (2001) Andragogy and Self-directed Learning: pillars of Adult Learning Theory. New Directions for Adults and Continuing Education 89:3-13.

Merriam, S. b. and R.S. Caffarelia ( 1999) Learning in Adulthood( 2nd Ed.) San Francisco: Jossey-Bass.

Mezirow, J. (2000). Learning to think like an adult: Core concepts of transformation theory. In J. Mezirow \& Associates (Eds.), Learning as transformation (pp. 3-34). San Francisco: Jossey-Bass

Moore, M.G. and Kearsley, G. (1996) Distance Education a system view. Belmont, Ca: Wadswort.

Perkins, D. N., and Salomon, G. (1992). Transfer of learning. Contribution to the International Encyclopedia of Education (2nd ed.). Oxford, England: Pergamon Press. Retrieved August 30, 2013, from http://learnweb.harvard.edu/alps/ thinking/docs/traencyn.htm

Tweedell, C.B. (2000) A Ttheory of Adult and Implications for Practice. Paper presented at the meeting of the Midwest Educational Research Association Annual Meeting Chicago Illinois.

UNESCO Institute for Lifelong Learning, (2009) The state and development of adult learning and education in Sub- Saharan Africa 
Regional Synthesis Report Compiled by John Aitchison and Hassana Alidou

Van Rooy, T (2001) Educating Educators of Adults in South Africa : Reflections on Unisa initiative in the field in Progressio Vol 23(2): 61-72.

Walters, S. (2006) Adult Learning within lifelong learning: a different lens and different Light Mackie R. (2006) School of Education and Development \& School of Adult and Higher Education University of KwaZulu-Natal Pietermaritzburg, South Africa. A new series started at No. 23, equivalent to old series Volume 23, No. 1.

World Conference for All (1990) Articles 1 The Framework for Action to Meet the Basic Learning Needs by 2000. Jomtien, Thailand 
